\title{
Homage to Quietanus
}

\author{
Jacques Mertzeisen \&t Jean-Pierre Luminet
}

$\mathrm{O}$ NE OF THE STOPS toward the southern end of the route des vins d'Alsace is the picturesque town of Rouffach, located roughly halfway between Colmar and Mulhouse. The vineyards where the grand cru Vorbourg is produced lie to the east of Rouffach amid the rolling foothills of the Vosges mountains. To the east is the Rhine plain and, on a clear day, visible in the distance beyond, the Schwarzwald.

A former convent, L'église des Récollets dédiés à sainte Catherine d'Alexandrie, can be found near the ramparts at the southern end of Rouffach's old town. Originally constructed between 1280 and 1300 following the arrival of a Franciscan community some decades earlier, L'église des Récollets, as is often the case, was embellished and remodeled a number of times over the centuries that followed.

On a wall in the cloister courtyard is a large sundial, a meter or so in diameter, encircled by a fresco. Dated August 16, 1617, the sundial depicts the solar system in a geocentric configuration. ${ }^{1}$ This was, of course, a time when the ideas of Nicolaus Copernicus, published just a few decades earlier, were still contested. But upon closer inspection, it can be seen that the sun, Mercury, and the earth are shown in conjunction, and Jupiter in opposition. Herein lies a puzzle. It was not until some thirty-five years later, in 1652, that such a configuration could be observed.

How to explain this disparity? And why should such an event be commemorated in, of all places, a small town in Alsace?

The answers to these questions, it seems, can be found in the story of a little-known seventeenth-century astronomer, Johannes Remus Quietanus.

Transits of Mercury are relatively rare. Mercury's orbit is inclined from that of the earth and the two planets do not move in the same plane. ${ }^{2}$ For this reason there are only about thirteen every century. The transit of Mercury on November 7, 1631, is particularly notable in the history of astronomy because it was the first to be predicted and observed using scientific methods. Pierre Gassendi, who observed the transit from Paris, was long believed to have been the only astronomer to publish an account of the event. ${ }^{3}$ But, as it turns out, there is a second account, based on observations made from Rouffach and addressed to Leopold V, the Archduke of Austria-Tyrol. ${ }^{4}$

Prior to the 1631 transit, observing an event of this nature had posed a number of problems for astronomers. Mercury obscures just $0.04 \%$ of the sun's surface during a transit, and even with the aid of a device such as a helioscope, which projects the image of the sun onto a screen, the event is barely noticeable. The first helioscope was invented by Christoph Scheiner, an astronomer and mathematician in Ingolstadt, not long before the 1631 transit. Precisely predicting the timing of a transit had also proven problematic. The first to calculate and publish an accurate forecast for the transit of Mercury was Johannes Kepler. His prediction for the 1631 transit appears in a note he wrote two years beforehand, Admonitio ad astronomos. ${ }^{5}$ Kepler did not live to see the event; he died on November 15,1630 .

A successful observation of the 1631 event was thus reliant on knowledge of both Kepler's note and the work of Scheiner-not to mention, of course, a considerable degree of skill and knowledge. The observer in Rouffach, who was also the author of the second account, knew what he was doing and how to do it.

That lone observer was Johannes Remus Quietanus.

Quietanus was born Johann Ruderauf on September 22, 1588, in the Thuringian town of Herda. As a young man, Ruderauf was enrolled at the University of Jena in 1605, where he likely studied law and theology. ${ }^{6}$ In the summer of 1607 , when Ruderauf was nineteen years old, a comet appeared in the night sky. Its apparition was the inspiration for Ruderauf to pen a fifty-page booklet entitled Gründliche Beschreibung des neuen monstrosischen Sternes welcher Anno Christi 1607 ...vom 27 Juli bis helfte october am hohen Himmel geleuchtet ("Precise Description of a New Monstrous Star which Shone at the Top of the Sky from 27 July to Mid-October in 1607"). ? In it, Ruderauf recorded the trajectory of the comet, noting its day-to-day position on a map of the sky. His observations are preceded by a lengthy preamble proclaiming the comet a sign from God concerning the Roman Catholic Church and the Republic of Venice. The comet was later named in honor of Edmond Halley, the English astronomer who discovered its period- 
icity. Halley's comet has an elliptical orbit that passes close to the sun roughly every seventy-six years, during which time it is visible for several months.

A year later, Kepler mentioned the Gründliche Beschreibung in a letter to the astronomer Joachim Tancke in Leipzig; he had evidently read it. ${ }^{8}$

At some point between 1607 and 1611 (the precise details are likely lost to time), Ruderauf moved to Padua to continue his studies. Kepler later wrote that Ruderauf had converted to Catholicism during his time in Italy, having been "in contact with the Inquisition," and changed his name to Johannes Remus Quietanus. ' In Latin, remus quietanus means "quiet rower," while the German Ruderauf designates the oar raised from a skiff. ${ }^{10}$

At the time, Padua was home to a university with a renowned medical school. Among those who taught at the university was Galileo Galilei. ${ }^{11}$ Writing to Galileo in 1619, Quietanus reminded him that "I met you in Padua ten years ago."12 Quietanus was also acquainted with a number of figures from Galileo's entourage, including Giovanni Faber, chancellor of the Accademia dei Lincei. According to Mordechai Feingold's Jesuit Science and the Republic of Letters, Quietanus passed through the College of Rome. ${ }^{13}$

In December of 1611 Quietanus, then twenty-three years old, wrote to Kepler for the first time, from Rome.

I have been in Italy for four years and have always carefully noted the eclipses ... [during] my journey [to] Sicily and Malta, I made some observations to probe the longitudes and latitudes of the places, as here also in Rome. ${ }^{14}$

Quietanus was keen to demonstrate that he had been keeping abreast of recent developments-in particular, of Kepler's Astronomia Nova, published two years earlier.

I saw your ingenious work on Stella [the planet] Mars. You are in agreement with Copernicus in the opinion that the Earth moves.... If this is the case, the fixed stars are very distant since no parallax is observed. ${ }^{15}$

Quietanus went on to mention the satellites of Jupiter, recently discovered by Galileo, as well as the precise duration of the equinoctial year. Kepler replied in March 1612, noting that the parallax of the fixed stars is negligible. ${ }^{16}$

Quietanus then appears to have settled in the Holy City for a time, where he was introduced into papal circles, and practiced astronomy. ${ }^{17}$ In correspondence with Faber after his stay in Italy, Quietanus often asked Faber to mention him to this or that cardinal, in particular, the Cardinal of Santa Susanna, Scipione Cobelluzzi, who was in charge of the Vatican library. ${ }^{18}$ Quietanus dedicated his treatise on universal celestial motion to Stefano Pignatelli, later a cardinal. ${ }^{19}$ Quietanus also published texts on lunar eclipses and comets during this period. ${ }^{20}$
In 1618, Quietanus departed Rome for Innsbruck to take up the position of doctor to Maximilian III, the Archduke of Austria. Upon his arrival, he was greeted by Scheiner, who had been summoned to work for the Archduke. It was probably Scheiner who introduced Quietanus to solar observation and the helioscope.

Maximilian III died in early November $1618 .^{21}$ Quietanus was subsequently appointed an Imperial doctor and awarded a substantial pay raise. While Quietanus was now doing quite nicely, the outlook for some of his patients was less rosy. In mid-December, the Empress, Anna of Tyrol, passed away. Her husband, the Emperor Mathias I, followed suit just three months later. ${ }^{22}$ Quietanus may have been an able astronomer, but as a physician his record seems less than stellar. ${ }^{23}$

Quietanus and Kepler resumed their correspondence in December 1618. The appointment of Quietanus as physician to Mathias I meant that the pair now had the same employer. In his letter, Quietanus provided an account of the recent conjunction of Venus with the moon..$^{24}$ Replying on December 1, Kepler congratulated Quietanus on his new position. In passing, he mentioned a disagreement with Galileo about whether the stars were illuminated by the sun or emitted their own light. Subsequent letters between the pair discuss the ban imposed by the Roman authorities on Kepler's Epitome astronomiae Copernicanae. ${ }^{25}$ In August 1619, Quietanus sent a copy to Galileo, who had been unable to find the work in Florence. Also enclosed was a commentary on the comets of 1618 and Kepler's own assessment. ${ }^{26}$ Quietanus thus found himself serving as an intermediary between the two masters of Copernican astronomy. ${ }^{27}$ After 1620, the correspondence with Kepler lapsed again for the eight years prior to Kepler's announcement of the 1631 transit of Mercury. ${ }^{28}$ By this time, Quietanus was already in Rouffach, having settled there in the early 1620 s.

In 1624, Quietanus published a calendar, Neuer Schreibkalender, auff das Jubel Jahr 1625, containing ephemerides, astral charts, and predictions of astronomical and meteorological phenomena. Quietanus may, in fact, have published a Schreibkalender each year; traces of ten editions have been found thus far. The annual Schreibkalender might have been how Quietanus earned his livelihood. In his calendar for 1631, the page for November notes a conjunction of Mercury with the sun, predicted for November 7, with the mention "Such Mercurius under der Sonn" (seek Mercury under the sun).

The 1641 edition, in the form of an almanac, is entitled Natürliche Practica und Witterung, auf dass Jahr 1642..9 Details for eclipses of the sun and moon are provided along with ephemerides and two sets of dates (Julian and Gregorian), based on Kepler's Rudolphine Tables. The Holy Roman Empire was a mosaic of unrelated states; when one passed from one state to another, the date might change by ten days, since the Gregorian 
calendar was not yet universally adopted. Quietanus was the first to use the new Rudolphine Tables to prepare calendars. ${ }^{30}$ The almanac also offers medical and gardening advice, long-term weather forecasts, and even predictions about the influence of eclipses on the quality of wine. As was not uncommon at the time, Quietanus mixes astronomy and astrology throughout. ${ }^{31}$ One chapter is devoted entirely to the war in Alsace-the Thirty Years' War had begun not long before Quietanus arrived in Rouffach. ${ }^{32}$

Quietanus lived the remainder of his life in Rouffach, dying at age sixty-six on October $17,1654 .{ }^{33}$

What should we make of the life and work of Johannes Remus Quietanus?

His correspondence with Kepler at times reveals some ambivalence on the part of the master concerning measurements provided by Quietanus. ${ }^{34}$ Nonetheless, the duo can often be found discussing questions and topics raised by Quietanus. ${ }^{35}$ These reflect the astronomical concerns of the time, such as comet trajectories, the dimensions of celestial bodies, and the measurement of longitude.

One such topic was the distance from the earth to the sun. From the work of Hipparchus in antiquity, it had long been believed that distance was 1,200 times the size of the earth's radius. In 1629, Kepler proposed a new figure of $3,400$ earth radii ( 21.8 million $\mathrm{km})$. The estimate offered by Quietanus was considerably larger at 14,000 earth radii ( 90 million km). "Our successors," Kepler remarked, "will decide." ${ }^{36}$ Neither was correct-the distance is 149.6 million $\mathrm{km}$-but the calculation by Quietanus was the closer of the two. It should be noted, however, that Quietanus used an erroneous hypothesis concerning the proportionality of the diameters of the planets and their distances from the sun. ${ }^{37}$

On the question of heliocentrism, Quietanus seems to have changed his mind several times. In 1628 , he wrote to Kepler that the model may work brilliantly for astronomical calculations, but the idea of a mobile earth had no basis in physical reality. ${ }^{38}$ In the Natürliche Practica auf das Jahr 1642 he wrote about the conjunction of Jupiter and Saturn, due to take place in the spring of 1643 . Here he took a resolutely heliocentric position, referring to "the sun, the true center of the Universe." ${ }^{39}$

Through his contacts with Kepler and Galileo, Quietanus had a front row seat to the Copernican revolution. But unlike his illustrious correspondents, and in the absence of any notable inventions or discoveries, the name Quietanus has faded from history.

And the sundial at L'église des Récollets? ${ }^{40}$ It seems possible that the fresco may have been originally designed by a contemporary of Quietanus, perhaps even under his supervision. Surviving to this day, it may thus constitute an anonymous homage.

Translated and adapted from the French by the editors.
Jacques Mertzeisen is an independent researcher in Strasbourg whose interests include sundials and the history of astronomy.

Jean-Pierre Luminet is Director of Research at the CNRS Astrophysics Laboratory in Marseille and the Paris Observatory.

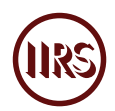

1. The date that appears above the sundial was added when the fresco was restored by René Rohr in 1979. The date that Rohr added, August 16, 1617, appears to be based on a miscalculation. Rohr, it seems, was unaware of both the story of Quietanus and his role in observing the 1631 transit of Mercury from Rouffach. For more details regarding the fresco see René Rohr, "La fresque du cadran solaire des Récollets à Rouffach," Cahiers alsaciens d'archéologie, d'art et d'histoire (1971): 109-15.

2. Jean-Eudes Arlot, ed., Le passage de Vénus (Les Ulis: EDP Sciences 2004)

3. See Albert Van Helden, "The Importance of the Transit of Mercury of 1631," Journal for the History of Astronomy 7 (1976): 1-10; Jean-Pierre Luminet, "Montaigne, Peiresc, Gassendi, and Cassini," Inference: International Review of Science 2, no. 4 (2016).

4. This text can be found in Historia Coelestis: Tycho Brahe, Historia coelestis ex libris commentariis manuscriptis observationum vicennalium viri generosi Tichonis Brahe Dani (Augsburg: Apud Simonem Utzschneiderum, 1666), 955-56.

5. Johannes Kepler, Admonitio ad astronomos, rerumqve coelestium studiosos, De raris mirisq; Anni 1631, Phœenomenis, veneris pvta et mercvrii in Solem incursu, Excerpta Ex Ephemeride Anni 1631. Et certo authoris consilio huic prcemissa, iterumq; Joannis Keppleri, edita à Jacobo Bartschio (Frankfurt: Gottfried Tambach, 1630).

6. The date of baptism for Ruderauf listed in Thüringer Pfarrerbuch, vol. 35-September 15, 1588 (Julian), September 25, 1588 (Gregorian)-as part of the entry for his father Jeremias Rudravius is in accordance with the date of birth Quietanus provides in a letter to Kepler dated March 13, 1619. The Thüringer Pfarrerbuch also mentions Quietanus enrolling at the University of Jena in 1605. See Bernhard Möller, ed., Thüringer Pfarrerbuch: Grossherzogtum Sachsen (-Weimar-Eisenach) - Landesteil Eisenach (Neustadt an der Aisch: Degener \& Co., 2000), 866; Letter 833 (March 13, 1619, Quietanus to Kepler) in Johannes Kepler, Gesammelte Werke: Briefe 1612-1620, vol. 17, eds. Walther von Dyck and Max Caspar (Munich: C. H. Beck, 1937-), 338.

7. Johann Rudrauff, Gründliche Beschreibung des neuen monstrosischen Sternes welcher Anno Christi 1607 ...vom 27 Juli bis helfte october am hohen Himmel geleuchtet (Erfurt, 1607).

8. See letter 472 (December 30, 1607, Joachim Tanckius to 
Kepler) in Johannes Kepler, Gesammelte Werke: Briefe 1607-1611, vol. 16, eds. Walther von Dyck and Max Caspar (Munich: C. H. Beck, 1937-), 423-24.

9. See letter 1,101 (February 24, 1629, Kepler to Albrecht von Wallenstein) in Johannes Kepler, Gesammelte Werke: Briefe 1620-1630, vol. 18, eds. Walther von Dyck and Max Caspar (Munich: C. H. Beck, 1937-), 383-84. According to a nineteenth-century source, Ruderauf was imprisoned in Italy c.1611. Ruderauf's father reportedly obtained his release through the intercession of Cardinal Scipione Cafarelli Borghese, protector of Germany under Pope Paul V. See Christoph Rommel, ed., Neuere Geschichte von Hessen, vol. 3 (Hamburg: Cassel, 1839), 321-22.

10. In a pamphlet published in 1642 he signs with both names: Discurs von der Zusammenkunft des zweyen höchsten Planeten, Johannes Remus Quietanus, sonst Ruderauffen von Herda (Colmar, 1642).

11. "L'astronomo tedesco Remus Quietanus, che, dopo avere studiato a Padova, era diventato medico e matematico imperiale." Germana Ernst and Laura Salvetti Firpo, “Tommaso Campanella e la cometa del 1618. Due lettere e un opuscolo epistolare inediti," Bruniana \&t Campanelliana 2, no. 1/2 (1996): 62.

12. "Te ante decennium Patavii cognovi." See letter 2,368 (dated January 12, 1619) in Galileo Galilei, Le opere di Galileo Galilei : edizione nazionale sotto gli auspicii di sua maesta il re d'Italia, vol. 12, ed. (Florence: G. Barbera, 1902), 433.

13. Mordechai Feingold, ed., Jesuit Science and the Republic of Letters (Cambridge, MA: MIT Press, 2003), 56, 81.

14. See letter 623 (December 17, 1611, Quietanus to Kepler) in Johannes Kepler, Gesammelte Werke: Briefe 1607-1611, vol. 16, eds. Walther von Dyck and Max Caspar (Munich: C. H. Beck, 1937-), 397.

15. See letter 623 (December 17, 1611, Quietanus to Kepler) in Johannes Kepler, Gesammelte Werke: Briefe 1607-1611, vol. 16, eds. Walther von Dyck and Max Caspar (Munich: C. H. Beck, 1937-), 396.

16. See letter 629 (March 18, 1612, Kepler to Quietanus) in Johannes Kepler, Gesammelte Werke: Briefe 1612-1620, vol. 17, eds. Walther von Dyck and Max Caspar (Munich: C. H. Beck, 1937-), 16.

17. In a letter to Galileo, in which he describes a parhelion observed from Kassel in January 1613, he asserts, "a Roma io non ho visto niente in quel tempo." See letter 1,417 (dated August 24, 1619) in Galileo Galilei, Le opere di Galileo Galilei : edizione nazionale sotto gli auspicii di sua maesta il re d'Italia, vol. 12, ed. (Florence: G. Barbera, 1902), 487.

18. Quietanus mentions Scipione Cobelluzzi in a letter to Kepler (dated March 13, 1619): "Romam Cardinali meo tituli S. Susannae qui etiam valde? delectatur Mathematicis, et olim fuit meus discipulus et jam est S. R. E. Bibliothecarius." See letter 833 (March 13, 1619, Quietanus to Kepler) in Johannes Kepler, Gesammelte Werke: Briefe 1612-1620, vol. 17, eds. Walther von Dyck and Max Caspar (Munich: C. H. Beck, 1937-), 338. Quietanus and his friend Faber maintained a long corre- spondence, most often in Italian, but also in German or Latin; the three languages are sometimes intermingled. The letters discuss current events, and political, economic, and medical considerations. The latter includes mentions of certain "metallic medicaments," such as drinkable gold, the elixir of youth sought by alchemists. For Quietanus, the sun and Mercury were not only objects of astronomical studies. They also had a place in his pharmacopoeia.

19. Johannes Remus Quietanus, Restitutio universalis Motuum caelestium in stellis fixis, sole, luna, et maxime eclipsibus. Cum annexo calculo et observationibus tam antiquis quam novis telescopii ope habitis, quo tandem fundamento iacto ad reliquorum motuum correctionem securus patet aditus per Ioannem Remum Quietanum Tyrigoetam Philosophiae et medicinae doctorem. Romae. Anno salutis nostrae MDCXV (Rome: 1615).

20. See Johannes Remus Quietanus, Observationes eclipsis lunaris anno Christi MDCXVI. XXVI. Augusti nocte sequente Romae habitae. Ex qua et aliis tribus exquisitis demonstrantur distantiae, magnitudines, \& proportions corporum ac sphaerarum Solis, \& Lunae, ac umbrae Terrenae, una cum comparatione calculi Alphonsini, Copernicaei, Brahaei, \&t Magini (Rome: Iacobi Mascardi, 1616); Johannes Remus Quietanus, Observationes et descriptiones duorum cometarum (Innsbruck: Daniel Pair, 1619). A copy of the latter can be found at the Academia dei Lincei in Rome.

21. Having apparently conducted an autopsy on Maximilian III, Quietanus described some morbid details-lungs filled with water, the color of the liver, the aspect of the kidneys-in a letter to Kepler. See letter 801 (October 20, 1618, Quietanus to Kepler) in Johannes Kepler, Gesammelte Werke: Briefe 1612-1620, vol. 17, eds. Walther von Dyck and Max Caspar (Munich: C. H. Beck, 1937-), 276.

22. A letter from Quietanus to Giovanni Faber dated June 29, 1619 that can be found in the archives of Accademia dei Lincei mentions an accompanying document "Anatomia della l'imperatore e l'imperatrice." Unfortunately, it appears that the attachment has been lost.

23. In 1628, after Quietanus had settled in Rouffach, two widows from the neighboring village of Gueberschwihr poisoned some guests with poor quality wine. The victims fared rather better than some former patients of the good doctor Quietanus. Using remedies typical of the time, such as purging, bleeding, and the administration of a few drops of mercury, Quietanus successfully treated the victims. The widows, on the other hand, were condemned for sorcery. (Archives départementales du Bas-Rhin, cote W2B10 Rouffach auj. cote 2B10.)

24. This event was observed in Lisbon by Johann Schreck.

25. Johannes Kepler, Epitome Astronomiae Copernicanae Usitata forma Quaestionum \& Responsionum conscripta, inque VII. Libros digesta, quorum Tres hi priores sunt de Doctrina Sphaerica (Frankfurt: Lentijs ad Danubium, Excudebat J. Plancus, 1617-21).

26. See letters 1,417 (August 24, 1619, Quietanus to Galileo) and 1,418 (August 24, 1619, Quietanus to Galileo) in Galileo Gal- 
ilei, Le opere di Galileo Galilei : edizione nazionale sotto gli auspicii di sua maesta il re d'Italia, vol. 12, ed. (Florence: G. Barbera, 1902), 487, 488.

27. For a discussion of the often stormy relationship between Kepler and Galileo, see "Kepler et Galilée, une rencontre manquée?” by Hervé Delime.

28. See letters 885 (June 20, 1620, Quietanus to Kepler) and 1,095 (1/11 December, 1628, Quietanus to Kepler) in Johannes Kepler, Gesammelte Werke: Briefe 1620-1630, vol. 18, eds. Walther von Dyck and Max Caspar (Munich: C. H. Beck, 1937-), 31, 549.

29. Johannes Remus Quietanus, Natuerliche Practica und Witterung; auf dass Jahr der Geburt Jesu Christi, M.DC.XLII. Jm 24. Jahr der beharrlichen Kriegen in Teutschlandt (Colmar, 1641). The almanac is credited to Johannes Remus Quietanus, philosopher and doctor of medicine, physician of the Hohenstifft of Strasbourg and the Obermundat of Rouffach.

30. Klaus-Dieter Herbst, "Die erstmalige Benutzung von Keplers Rudolphinischen Tafeln für die Herstellung eines Schreibkalenders" (The First Use of Kepler's Rudolphine Tables for the Production of a Writing Calendar) Acta Historica Astronomiae 40 (2010): 160-69.

31. See, for example, Johannes Remus Quietanus, Astronomischer und astrologischer Discurs von der grossen Zusammenkunfft ... der zweyen höchsten Planeten ... des Saturni u. Jupiters (Colmar, 1642).

32. Quietanus described the political and military situation in Alsace in letters to his friend Giovanni Faber. He reports the state of the forces on each side and tells of sacking, looting, fires and hostage-taking in the manner of a war correspondent. Some of the letters can be viewed in the digital archives of the Accademia dei Lincei.

When Swedish troops arrived in Rouffach on February 15, 1634, Quietanus paid a ransom to spare a Jesuit the soldiers had begun to torture after having killed several other monks. See Joseph Geny, Die Jahrbucher Der Jesuiten Zu Schlettstadt Und Rufach, 1615-1765 (Strasbourg: Le Roux 1896), 23, $586,619$.

33. Other than the date of his death, no further details are available. (Archives de Rouffach, registres paroissiaux)

34. "[w]enn Deine Beobachtungen zuverlässig wären; aber daran zweifle ich." (If your observations were reliable; but I doubt it...) See letter 1,103 (March 2, 1629, Kepler to Quietanus) in Johannes Kepler, Gesammelte Werke: Briefe 1620-1630, vol. 18, eds. Walther von Dyck and Max Caspar (Munich: C. H. Beck, 1937-), 554.

35. See letters $629,801,812,813,833,845,846,848$, and 850 in Johannes Kepler, Gesammelte Werke: Briefe 1612-1620, vol.
17, eds. Walther von Dyck and Max Caspar (Munich: C. H. Beck, 1937-), 16, 276, 292, 294, 337, 362, 363, 371, 375.

36. See letter 1,101 (February 24, 1629, Kepler to Albrecht von Wallenstein) in Johannes Kepler, Gesammelte Werke: Briefe $\underline{1620-1630}$, vol. 18, eds. Walther von Dyck and Max Caspar (Munich: C. H. Beck, 1937-), 383-84.

37. See Tycho Brahe, Historia coelestis ex libris commentariis manuscriptis observationum vicennalium viri generosi Tichonis Brahe Dani (Augsburg: Apud Simonem Utzschneiderum, 1666), 956.

38. "In Ellipsibus Planetarum tecum consentio ... Hypothesin terrae mobilis Mathematice? assumo et demonstro, nam physice? nec licet nec opus est mihi." See letter 1,095 (December 1/11, 1628, Quietanus to Kepler) in Johannes Kepler, Gesammelte Werke: Briefe 1620-1630, vol. 18, eds. Walther von Dyck and Max Caspar (Munich: C. H. Beck, 1937-), 370.

39. See the section "von Fried und Unfrieden" in Johannes Remus Quietanus, Natuerliche Practica und Witterung, auf dass Jahr der Geburt Jesu Christi, M.DC.XLII. Jm 24. Jahr der beharrlichen Kriegen in Teutschlandt (Colmar, 1641).

40. In the nave of L'église des Récollets is a tombstone dated February 27, 1635 bearing the inscription "Maria Schlitzweck, honest matron, wife of the noble and most excellent Dr. J. Remus Quietanus, physician of the serene Archduke Leopold."

In October 1619, Quietanus wrote to Kepler inquiring about the configuration of the planets on July 16, 1597. Quietanus appears to be seeking advice to cast a horoscope for his "sponsa" (bride). Curiously, Schlitzweck was born in Rouffach on August 17, 1597. See letter 855 (October 11, 1619, Quietanus to Kepler) in Johannes Kepler, Gesammelte Werke: Briefe 1612-1620, vol. 17, eds. Walther von Dyck and Max Caspar (Munich: C. H. Beck, 1937-), 394.

On June 15, 1620, Quietanus observed a lunar eclipse in Soultz (a village located about dozen or so kilometers to the south of Rouffach). Quietanus notes that he was in Soultz for a wedding feast. Perhaps it was his own? See letter 885 (June 20, 1620, Quietanus to Kepler) in Johannes Kepler, Gesammelte Werke: Briefe 1620-1630, vol. 18, eds. Walther von Dyck and Max Caspar (Munich: C. H. Beck, 1937-), 33.

Three years later, Schlitzweck gave birth to a son. (Archives de Rouffach, registres paroissiaux) Nothing more is known of the son's fate; he may well have died in his infancy.

Schlitzweck's epitaph states that she lived thirty seven years, six months and eleven days. Fifteen years later, Quietanus married again; his second wife was Maria Helena Freudenstehlin, born in Ensisheim. (Archives de Rouffach, registres paroissiaux) 